\title{
Media Ethnography in Diasporic Communities
}

\author{
Putut Widjanarko \\ Paramadina Graduate School of Communication, Universitas Paramadina, Indonesia \\ Email: putut.widjanarko@gmail.com
}

\begin{abstract}
Media and communication technology plays a crucial role in diasporic communities by helping members to maintain complex connections with their places of origin, and at the same time to live their life in the diaspora. The social interactions, belief systems, identity struggles, and the daily life of diasporic communities are indeed reflected in their media consumption and production. A researcher can apply media ethnography to uncover some of the deeper meanings of diasporic experiences. However, a researcher should not take media ethnographic methods lightly since a variety of issues must be addressed to justify its use as a legitimate approach. This article examines various forms of media ethnographic fieldwork (multi-sited ethnography), issues related to researching one's own community (native ethnography), and the debates surrounding duration of immersion in ethnography research within the context of diasporic communities. Careful consideration of such issues is also necessary to establish the "ethnographic authority" of the researcher.
\end{abstract}

Keywords: diaspora; ethnography; media; multi-sited; native

\section{INTRODUCTION}

Economic globalization and advances in transportation technology have made the migration from one place to another easier, both within one country and between countries globally. Some of these human movements result in a group of people living for relatively long periods, or even permanently, in places that are not their native land or origin. In this article, the term diaspora is used to identify this social phenomenon. It should be recognized however that diasporic communities exhibit characteristics that go far beyond early definitions of the phenomenon. Previously, Gilroy (1994) stated that diasporas are produced by push factors such as slavery, pogroms, genocide, and other terrors that forced the community to disperse reluctantly. Today human migration is recognized as being influenced by much more than push factors; there are economic, cultural, and educational forces to consider in attempting to understand a diaspora

One important element that distinguishes today's diasporic communities from their predecessors is their ease in establishing contact, in whatever form, with their native lands, as well as with people who originated from the same place but are scattered in various parts of the globe, thanks to advances in communication technology and media. The migration of this group of people has deterritorialized them from their origins, causing cultural disruptions as well as adaptations. In their new homes, the deterritorialized people attempt to re-establish their cultural memories in the process of reterritorialization by creating a new cultural presence in the foreign lands. At the same time, they actively support or even establish local rituals at their origin hometowns or villages. In this sense, as Indiyanto (2012) asserts, the local and the global are in complementary positions instead of binary opposite positions.

According to Appadurai (1996), the media and migration, or mediation and motion, are "a constitutive feature of modern subjectivity" (p. 3), and "for migrants, both the politics of adaptation to new environments and the stimulus to move or return are deeply affected by a massmediated imaginary that frequently transcends national 
space" (p. 6). The Internet, social media, television, radio, are the arena where cultural forms are embodied in the forms of symbolic representations, which then are disseminated and distributed for interaction with other cultural forms. As Murphy \& Kraidy (2003, p. 7) stated, “... while globalization may be discursively situated in terms of broad economic, political, and cultural trends, media consumption is one of the defining activities of the global-local nexus as it is perhaps the most immediate, consistent and pervasive way in which "globality" is experienced." Unsurprisingly, the role of both production and consumption of media in the context of diasporic people has been researched by many scholars (e.g., Diraj, 2010; Setianto, 2016; Shumow, 2010; Sun \& Sinclair, 2016; Widjanarko, 2007).

Ethnography is a common approach to researching diasporic communities, especially for studies of the role of media in the life of these migrant communities. This is because ethnography can unravel "the nature of locality as a lived experience in a globalized, deterritorialized world" (Appadurai, 1996, p. 52). It also "brings forth the significance of the researchers' field experience, framed by location, culture, gender, race, class, and ethnicity" (Junnilainen \& Luhtakallio, 2015, p. 2). Media ethnography, indeed, promises to uncover the deeper meaning of the social interactions, behaviors, belief systems, and the life of diasporic group, as reflected in the media consumption and production of these communities.

It should be noted that some issues need to be addressed to better establish media ethnography as a legitimate method for researching diasporic communities. Ethnography in diasporic communities indeed still maintains the basic tenets of classical/conventional ethnography, such as immersion in the natural setting. However, it also subverts other tenets of classical/ conventional ethnography, such as the nature of sites, the relation of the researcher and the community, and the duration of the ethnography. Careful consideration of such issues will lead to a better understanding of the efficacy and the limitations of this form of ethnography. Attention to such matters will also determine the "ethnographic authority" of a researcher because professional credibility needs to be established rather than taken for granted or assumed. After carefully elucidating some essential features of ethnography, this article argues that media ethnography is an appropriate method to research diasporic communities.

\section{ETHNOGRAPHY IN MEDIA STUDIES}

Before delving into the issues pertaining to its application in diasporic communities, a discussion on the ethnographic method in media studies is first in order. Ethnography, as a research method, has been well-established in the media studies tradition (Tosoni \& Stiernstedt, 2016). It began to expand in the 1980s as an alternative to media research driven by survey and content analysis (Junnilainen \& Luhtakallio, 2015). It corresponds with the growing acceptance in cultural media (or audience) research that the audience has polysemic power in consuming and interpreting media, unlike other paradigms of research in media such as the "effect" model (as well as content analysis, uses and gratifications, and other approaches).

The first generation of audience research was articulated by Hall (1973) with his influential article on encoding and decoding. By asserting that audiences have several possibilities to decode (i.e., hegemonic, resistance, or negotiated decoding) the message, Hall showed the fact that the interaction between media and audiences was not unidirectional and straightforward. Media scholars used this paradigm in their research, by basically analyzing the messages or content of-for example, a particular television program or serial - and how audiences dealt with the message. Because in many cases it involved semiotic analysis, it is sometimes referred to as a semiotic or linguistic turn in audience studies.

The second generation of cultural audience research emphasizes the application of an ethnographic method in research (Alasuutari, 1999), hence the ethnographic turn in audience studies. In this tradition, media scholars study the everyday life of a group of people and how a particular program or medium is used or is related to those people. This tradition produces classic qualitative audience studies, such as those conducted by Ang (1985) on the audience of television serial Dallas and Radway (1984) on readers of romance novels.

The third generation was started when scholars (such as Allor, 1988; Bird, 1992; Grossberg, 1988; Radway, 1988) began to question the notion of the audience in cultural media studies. The criticism emphasizes that there is no such thing as "the audience" out there, except in the perception of scholars or media producers. In Allor's (1988) words, “The audience exists nowhere; it inhabits no real space, only positions within analytic discourse" (p. 288). Alternatively, in Bird's (2003, p. 185) words, "...the audience is not a discrete, bounded entity sitting still to be studied...".

This reexamination is perhaps best captured in the catchphrases they employ to describe the notion of the audience: the nomadic and dispersed audience (Radway, 1988), the wandering audience (Grossberg, 1988), and the impossible audience (Bird, 1992). The third generation 
approach espouses a broadened framework in conceiving media and media use in people's daily lives beyond analyzing a genre or a show. In other words, it focuses it on contextualizing and seeking connections between media, audience, and the broader culture. We can sense that McLuhan's (1964) famous aphorism, "the medium is the message," resonates in this approach.

This issue on the nature of the audience is even more relevant nowadays, along with the increasingly widespread and deepening scope of globalization everywhere (Bhandari, 2019; Junnilainen \& Luhtakallio, 2015; Murphy, 2011; Tosoni \& Stiernstedt, 2016). The local diasporic life of migrants is undoubtedly very much interlinked with this global media experience. Therefore, media ethnography as a method to unravel the use, consumption, and production of content and media in such social settings is justified.

Nevertheless, a media ethnographer must not claim to be able to unravel the complete truth about the group of society she or he is studying. The essential criticism of ethnography by positivists "is that it represents a phenomenon from a single perspective and offers little opportunity for confirmation by other researchers" (Paterson, 2017, p. 110). Indeed, as Ang (1996) has pointed out on her ethnography study of the television audience, the meaning attributed by the audience on the television program they are watching is contingent and contextual, depending on any specific situation in which the people consume the television (technological, psychological, and social). Therefore, she wrote, "as a result of this contingency meaning, the range of potential variety in audience practices and experiences becomes exponentially multiplied, indefinite, indeed, if not infinite" (p. 251).

By implication, in order to fully grasp the meanings, the researchers need to posit themselves "everywhere," and be "ceaselessly trying to capture a relentlessly expanding field of contextuality overdetermined, particular realities" (p. 254). Such a position, of course, is impossible, since there would be no research, no matter how ethnographic, which could fully capture real life. Ang suggests that the solution is to admit that an ethnographer, including the ones who research diasporic communities, “... cannot be 'everywhere' but must always speak and write from 'somewhere"' (p. 254).

\section{MULTI-SITED ETHNOGRAPHY}

Classical/conventional ethnography is usually associated with doing field research on a group of more or less homogenous people living in a more or less clearly bounded place - a village, for example. On the contrary, diasporic communities commonly reside in dispersed locations among the locals or even with other diasporic communities from other parts of the world. In responding to such challenges posed by globalization, some scholars have proposed approaches in which ethnography can be utilized in the research. These proposals come in different terminologies, such as multi-sited ethnography (Marcus, 1995, 1999, 2002, 2011), globography (Hendry, 2003), global ethnography (Buroway, 2000; Gille \& Riain, 2002), ethnography in the third time-space (Lavie \& Swendenburg, 1996), and translocal ethnography (Kraidy \& Murphy, 2003).

Most of the approaches mentioned above are variations of Marcus's multi-sited ethnography, which has been accepted as common practice ethnography. According to Falzon (2009), "In terms of method, multisited ethnography involves a spatially dispersed field through which the ethnographer moves - actually, via sojourns in two or more places, or conceptually, by means of techniques of the juxtaposition of data." (p. 2). Marcus (1995), in his most well-known and earliest article on this approach, argues that multi-sited ethnography considers global forces as integral parts of the daily life of the people. These forces were embedded in the connections among sites, even though those sites are spatially separated or take different forms. Therefore, for Marcus,

Multi-sited research is designed around chains, paths, threads, conjunctions, or juxtapositions of locations in which the ethnographer establishes some form of literal, physical presence, with an explicit, posited logic of association or connection among sites that in fact defines the argument of the ethnography. (p. 105)

For this reason Marcus (1995) identified six possible techniques for multi-sited ethnography, which might be seen as the initial springboard to launch the research with the expectation that it will be malleable and contingent upon the progress of the researcher. The first, follow the people, occurs where ethnographers follow and stay with the movement of the subject from one site to another. Second, follow the thing, has ethnographers follow the circulation of objects of study (such as commodities, gifts, works of art, etc.) through different contexts. Third, follow the metaphor, happens when ethnographers trace something within the realm of discourse (signs, symbols, and metaphors), such as the multi-sited research on AIDS. In the fourth, follow the plot, story, or allegory, ethnographers trace stories or narratives in different locales. Five, follow the life or 
biography, is where ethnographers design the research around the life history of a particular individual. Finally, six, follow the conflict, is where ethnographers deal with parties who are involved in a conflict, a technique that can be used in the context of anthropology of law.

Later, Marcus (1999) distinguished two approaches in practicing multi-sited ethnography, i.e., obvious and non-obvious paradigms. When an ethnographer visits different locations to track the movement of migrants, or the circulation of cultural objects to study the relationship of dispersed communities and their networks, or to follow the allegory or conflict, he or she is conducting an obvious multi-sited ethnography, since the relation of the sites is clear and obvious. The research (interviews and observation) can be done in many physical sitessuch as houses of worship, private homes, public gatherings, ethnic restaurants, ethnic groceries, and other places.

However, there are cases where the relationship and connections between sites are not physical, direct, and clear - in terms of space, time, or social category as well. This issue is dealt with by the non-obvious paradigm of multi-sited ethnography. In this case, multi-sited research does not have to be conducted in several different physical sites. Even though there might be few actual contacts between the sites, what happened in one of the sites is influenced by the imagining of what is going on at the other sites. For Marcus (1999), "Multi-sited research involves innovative ways of bounding the potentially unbounded" (p. 9). Hence, with such an approach, an ethnographer can conduct research on diasporic communities through various media they produce. In this sense, she or he could examine the media, such as printed media the community produces, the Internet (electronic mailing lists, websites) as well as their social media.

\section{ON THE "PURITY OF SITES"}

Another challenge confronting the ethnographic method in the globalized and diasporic communities is the notion of the field. This notion has been taken for granted for so long and largely overlooked in the discourse of current anthropology and ethnography. Historically, the introduction of the notions of field and fieldwork in anthropology was inspired by the development of natural sciences (such as zoology, botany, and geology) in the late $19^{\text {th }}$ and early $20^{\text {th }}$ centuries (Kuklick, 1997). Therefore, following the natural sciences, the more "natural" the field, the more it is desirable as a site of research. It leads to what Gupta \& Ferguson (1997) have called the hierarchy of purity of field sites, in which some places are more "field-like" than others.
All ethnographic research is thus done "in the field," but some "fields" are more equal than others-specifically, those that are understood to be distant, exotic, and strange. ... [I]t remains evident that what many would deny in theory continues to be in practice: some places are much more "anthropological" than others (e.g., Africa more than Europe, southern Europe more than northern Europe, villages more than cities) according to the degree of Otherness from archetypal anthropological "home." (p. 13)

In this sense, New York City, Hong Kong, Taiwan, and other big cities as a field site for an ethnographer from Indonesia, for example, is an oxymoron. It does not fit with the archetypal classical ethnographic home.

Fortunately, as Gupta \& Ferguson (1997) and Ferguson (2009) show, there have been efforts to rethink the idea of the field by decentering and rejecting the hierarchy of field sites. Decentering of field sites acknowledges "different forms of knowledge available from different social and political locations" (Gupta \& Ferguson, 1997, p. 37). Thus, the production of ethnography should not only be based on the commitment to location and the presence of the ethnographer, but should also acknowledge different forms of knowledge, such as archives, mass media, public discourse, and novels. For example, a study of a diasporic community that receives heavy media coverage will require the ethnographer to examine the content of the media about the community besides the traditional fieldwork. It is possible that the members of such a community represent themselves according to how the media represent them. In other words, an ethnographer needs to consider various "forms of knowledge" in the community he or she is studying in addition to the traditional observation and participation.

Meanwhile, rejecting the hierarchy of purity of field sites does not mean rejecting the notion of the field altogether. There are still places that can be fields for ethnographers to travel to, because if the field is everywhere, then it is nowhere. Clifford (1997) maintains that there are three anthropological legacies of what constitutes of fieldwork: the role of travel, physical displacement, and temporary dwelling away from home. As Clifford has stated, “. . . some form of travel, of disciplined displacement in and out of one's 'community' (seldom a single place, in any event), will probably remain the norm. . . Travel, redefined and broadened, will remain constitutive of fieldwork, at least in the near term" (p. 89). 
Gupta \& Ferguson's (1997) rejection of the hierarchy of purity of field sites and Clifford's (1997) assertion of the three anthropological legacies (the role of travel, physical displacement, and temporary dwelling away from home) that constitute fieldwork justify ethnographical research in the big cities. Therefore, for a media ethnographer, the metropolitan New York City, Hong Kong, or Taipei is a justified field site where she or he could research a diasporic community.

\section{ISSUES ON NATIVE ETHNOGRAPHY}

Many studies on diasporic communities are done by ethnographers from the same ethnic groups or nationalities with those communities, including studies on Indonesian diaspora (e.g., Setianto, 2016; Wardana, 2013; Widjanarko, 2007; Zulfikar, 2014). In such a research scenario, the issue of native ethnography needs to be understood. Clifford (1986, p. 9) pointed out that "A new figure has entered the scene, the 'indigenous ethnographers' . . . Insiders studying their own cultures offer new angles of vision and depths of understanding. Their accounts are empowered and restricted in unique ways." Clifford was writing, of course, in the spirit of elucidating the seismic changes in ethnography in response to the current postmodern condition in which the presence of indigenous ethnographers has, among other things, unsettled one of the foundations of anthropology: the issue of "Othering" (Abdelrahmen, 2015).

Interest in studying one's own culture increased from the 1960s onwards, in both the newly independent countries of the so-called Third World, where indigenous scholars started participating in the production of knowledge, and North America, which became a magnet for international students (Altorki \& Fawzi El-Solh, 1988a). This growth reached a critical point in the late 1970s and early 1980s when scholars started thinking about inherent issues of indigenous ethnography, such as the advantages and disadvantages of being closely intimate with the culture under study. Debates proliferated over the concept of representation (Who are the "natives"?), or even if there is such a thing.

The growth of interest in this issue is also reflected by the plethora of names used by scholars to label their research: e.g., insider research, autoethnography, indigenous ethnography, native research, introspective research, endogenous research, incultural research, and peer-group research (Messerschmidt, 1981). Indeed, although the terms "indigenous" and "native" are used interchangeably (Balzer, 1995), as are "indigenous" and "insider" (Altorki \& Fawzi El-Solh, 1988b), the term "native" was more frequently used in the literature of the period. This is understandable since the term "native" was widely utilized in ethnography, as in the oft-used phrase "going native" - the root of which can be traced back to Malinowksi (1961) when he suggested that "to grasp the native's point of view, his relationship to life, to realize his vision of his world" (p. 290), an anthropologist should "go native."

However, the term "native" as an adjective of anthropology or ethnography is not unproblematic, especially in the historical context of power and knowledge. It has deep roots in colonialism when the colonized people were referred to as natives (Asad, 2002). Therefore, as Appadurai (1988) puts it, the word "native" tends to be used for people who are "distant from the metropolitan West. ... Natives are in one place, a place to which explorers, administrators, missionaries, and eventually anthropologists, come. . ." (pp. 3637). In Weston's (1997) words, "If one is not born an anthropologist, neither is one born a native. Natives are produced as the object of study that ethnographers make for themselves" (p. 166).

Some scholars deliberately decided to use the word native to describe themselves or their methodology. Balzer (1995), neglecting the colonial roots of the word, felt relatively comfortable with the word, and was willing to describe herself as a "native anthropologist." On the other hand, Kuwayama (2004) has deliberately used the term "native anthropology" for three reasons,

First, it testifies to the "colonial roots" of anthropology. Second, it draws attention to the 'intrusion' into the academic space of former colonial powers by their subjects. And third, this intrusion signals the radical change taking place in the structure of anthropological knowledge. (p. 3)

Meanwhile, Kraidy (1996) used the term "native" instead of "indigenous" for the reasons unrelated to the issue of colonialism. Kraidy argued that "The word 'native,' although it denotes authenticity and localism, connotatively englobes a spatial movement, a certain displacement" (p. 66). The term "native ethnography" is more commonly used now in many studies later (e.g., Abdelrahmen, 2015; Yoshimura, 2015).

Several further points need to be addressed on this issue. First of all, sharing the same geographic, ethnic, and national background with the people being studied does not automatically make an ethnographer "native". Taking the native designation overlooks the possibility of differences - in terms of gender, class, education, etc.between the ethnographers and the people being studied 
that might hinder the ability of the researchers to immerse themselves in the culture they are studying.

Koentjaraningrat (1982), has informed us how the Javanese youth quite quickly accepted him in the villages he was studying. On the other hand, although himself a Javanese, he had had some difficulties in approaching the older people, because they saw him similar to and in the same category as government officials. In another case, he was studying Indonesian Papuan sago gatherers. Although he could converse with them in the eastern dialect version of Indonesian, he felt an atmosphere of suspicion, probably because ". . . I was considered not only a genuine stranger but one who belonged to another nation of colonizers, similar to the Dutch or Japanese" (p. 180). Being an unmarried woman, Altorki (1988) was restricted in her access to men, although she could work with women when she was studying in her native city, Jiddah, Saudi Arabia. Võ (2000) faced similar problems when she was studying Asian Americans in San Diego. In this sense, "native" is a fluid category, and its meaning is dependent upon the social context (Abdelrahmen, 2015; Abu-Lughod, 1988; Acosta-Alzuru, 2005; Aguilar, 1981; Hannoum, 2011; Jacobs-Huey, 2002; Kuwayama, 2004; Ryang, 2005).

This fluidity does not mean that native ethnographers have no differences from, say, non-native ethnographers. In fact, there are claims and counterclaims about the advantages of being one, and what are seen as advantages by proponents of native ethnography are, at the same time considered to be disadvantaged by its critics (Aguilar, 1981; Altorki \& Fwazi El-Solh, 1988b; JacobsHuey, 2002). The most often mentioned claim is that a native ethnographer will have a relatively closer distance to the societies he or she is about to represent than will the non-native ethnographer by virtue of shared cultural roots and languages. As such, preexisting experiences offer the possibility for the ethnographer to be able to more quickly uncover and attach meanings to patterns encountered in that society - since the ethnographer can understand "a social reality on the basis of minimal clues" (Altorki \& Fwazi El-Solh, 1988b, pp. 7-8). Also, it is held that native status ensures access to all information and cultural patterns in the society without altering the social settings, given the fact that native ethnographers are able to blend into situations more smoothly. In other words, if non-native ethnographers are going out to a field, native ethnographers are returning to a field (Clifford, 1997).

Nevertheless, it is their very familiarity with the culture that is criticized as possibly causing the ethnographers to fail to notice important cultural evidence. Being already immersed in the culture, they may take the clues for granted. Conversely, being a stranger in the culture, the non-native ethnographer is more readily aware of any clues. In this sense, to produce excellent research, ethnographers need to be able to perform what Aguilar (1981) has put succinctly: "Thus, the outsider must to some extent get into the natives' heads, skins, or shoes, whereas the insider must get out his or her own" (pp. 23-24).

Doing native ethnography research on the diasporic community is posed with the same challenges delineated above. However, being aware of the possible disadvantages of being a native, the ethnographer has to bear in mind this issue throughout the research by continually trying to see things from an outsider's perspective by asking herself why such and such happened in a particular way. While she might not always be successful in her vigilance to maintain an outsider's perspective, this awareness will lead the ethnographer, to a large degree, to make "strange" the assumingly familiar diasporic life.

\section{AVOIDING THE CURSE OF BLITZKRIEG ETHNOGRAPHY}

How long is media ethnography research on a diasporic community ethnographic enough? Indeed, the length of time of an ethnographer to live or stay in the field is one of the most debated issues in contemporary ethnography. Malinowski, considered as the "father of ethnography," lived among the Trobrianders for two years during World War I, a period that then became a kind of convention, especially for doctoral students in anthropology, in doing their fieldwork. Later, one year of fieldwork became the norm as well, assuming that living one year with the "natives" would enable anthropologists, again especially doctoral students, to observe one full cycle of activities (Jeffery \& Troman, 2004). What about staying three to four months on the field? Is such a research one of what Rits (1980) has called pejoratively "blitzkrieg ethnography"?

What Rits (1980), a trained anthropologist, criticized primarily was the practice of his colleagues' educational researchers who had used ethnography as a mantle for works that were "shoddy, poorly conducted, and ill-conceived" (p. 8), and ignored the epistemological underpinnings of ethnography. He lamented that ethnography was no longer practiced as it used to be: no traditional "rite of passage" when a novice anthropologist must go to the field for an extended time and enmeshed in the life of the site, and ethnographic research had been conducted by scholars who had not had experience in doing so. The same criticisms were also put forward by 
Wolcott (1999) to what was so-called "rapid assessment procedures," used to label quick ethnographic research social-impact assessments, such as forestry, animal husbandry, AIDS, etc.

To counter such criticism, Hannerz's (2003) discussion of his multi-site ethnography research on news media foreign correspondents is useful. To begin with, he points out that, especially in a diasporic community, people are less dependent on the annual cycle of seasons - "on planting and harvesting, or on moving herds to greener pastures" (p. 209). Furthermore, he argues that even the sites of the multi-sited research might be short-lived phenomena, as was his study, which relied on international conferences, workshops, or press conferences as the sites.

In some cases, even the "natives" are ephemeral, as shown by Couldry's (2003) research on the Granada Studio Tour (the shooting location of well-known television series Coronation Street) in Manchester, England. He believes that the studio was worth studying because it shows how people interact with media and live in a mediated world.

The traditional ethnography model surely will not work in such research settings since "people come together on a temporary basis, often without the knowledge of each other's full context for being there" ( $p$. 51). He conducted a participant-observation study and a large number of open-ended interviews with the visitors, but no follow-up interviews at home. The approach was to engage with as much context as possible for the passing visitors and the reflections they made on navigating the mediated world they were experiencing. Therefore, "The result is a 'passing ethnography,' but one no less serious at that. It represents a serious commitment to engage with the texture of our dispersed but mediated lives" ( $p$. 53). These examples show that if a group of people or a site is considered to be worth studying ethnographically, and the extended time of fieldwork is difficult to maintain because of the nature of the people and the site itself, then the extended time could be a non-factor in the research.

Meanwhile, Jeffrey \& Troman (2004) proposed what they called "a compressed time mode" ethnography to avoid blitzkrieg ethnography, a designation for the intense ethnographic research in which researchers inhabit the site "almost permanently for anything from a few days to a month" (p. 538). At the site, researchers must do a lot of "hanging around", absorbing as much as they can of every tiny detail of daily routines, and observation becomes the spearhead of the research. More or less, the same approach is taken by Isaacs (2016) when she does her fieldwork in a fast-paced corporate and business setting through what she calls "rapid ethnography." She has proved that well designed and executed rapid ethnography will provide the researcher with specific and long lasting benefit. Furthermore, for Knoblauch (2005), to conduct a "focused ethnography," the approach he proposes is one that requires a large amount of work in the preparation and the analysis of data collected in the field, despite the shorter visit to the field. To summarize, Knoblauch (2005) asserts that "... [a focused ethnography] is one legitimate and respectable instrument in the field of ethnographic research" (p. 2).

Pink \& Morgan (2013) argue further that what they call "short-term ethnography" is not an inferior way to research compared to a long-term ethnographic immersion, but "it is rather a route to producing alternative ways of knowing about and with people and the environments of which they are part" (p. 359). For them, obtrusive ethnography is the key of the short-term ethnography they propose, in which "the ethnographer seeks to implicate her or himself at the center of the action, right from the start, and engages participants in the project with this intention clearly stated" (p. 355). There is a difference between short-term and long-term ethnography in terms of the "conversation" between what happens in the fieldwork and the theory. In longterm research, the ethnographic-theoretical dialog is less intense, and it might take place at several points of time during the research (in a conference or preliminary work presentation to colleagues, for example). The ethnographer could concentrate on the observation and data collection first for a considerable amount of time and engage them with the theory later. On the contrary, Pink \& Morgan (2013) argue, in short-term ethnography, the dialogue between theory and ethnography should be maintained more intensely as the research develops, not only because of the limitation of time but also because the research question is more specific and pinpointed. This strategy, certainly, can be adopted by a media ethnographer researching a diasporic community.

Furthermore, as previously mentioned, many researchers working on diasporic communities are native ethnographers. The fact of being a native, with his or her preexisting knowledge and experience, is also a factor that can speed up the ethnography. As Jacobs-Huey (2002) stated, language and discourse knowledge are useful in understanding the culture quicker than can be done by outsiders. The "native-ness" of ethnographers is also mentioned by Marcus (1998) as one of the issues when he replied to the criticism that claims that multi-sited ethnography had undermined the "depth" or substance of fieldwork. In the traditional Malinowskian fieldwork 
model, depth could be attained only by living several years in the fieldwork in order for the ethnographers to discover how the society functioned around such topics as kinship, rituals, social institutions and structures, etc. However, Marcus argues that the emphasis on reflexivity in the design and the construction of multi-sited ethnographic fieldwork could maintain the depth of the research result. The question of identity, which is related to the researcher's preexisting extent of relationship and the connection to the community under study, has become important. In other words, a researcher's ethnic or national affiliation with the diasporic community becomes advantageous in shorter-term ethnography.

\section{CONCLUSION}

Globality and locality, as well as identity and issues of belonging (Indiyanto, 2012), are strongly reflected in media consumption and production behavior in both individuals and collectives in the diasporic community. Various media forms, whether it is printed (books, magazines, newspapers, etc.), audiovisual (photography, video, CD, DVD, etc.), digital (social media, websites, online news, etc.), and even what Morley (2000) called as "small media" (posters, pictures and ethnic nuances of ornaments mounted on the walls of the house, etc.), have become representations of the diasporic life struggle. Therefore, to unravel the deeper meanings of these diasporic experiences, a researcher is strongly advised to use media ethnography.

Ethnographers should consider and recognize issues related to the use of ethnographic media in a diasporic context as an evolving methodology. In many cases, techniques that have only recently been accepted may contradict classical/conventional ethnography, which is mainly applied in the field of anthropology. By acknowledging these issues, ethnographers will be able to realize the strengths, weaknesses, capabilities, and limitations of media ethnography so that they can conduct research and report the results of their research appropriately, hence establishing her or his "ethnographic authority." Multi-sitedness, the status of sites, the "nativeness" of the ethnographers and the length of fieldwork do not limit the efficacy of media ethnography in diasporic communities.

Finally, no matter how sophisticated the research that is carried out, media ethnography does not claim the results of research as a single truth. One of the main underlying paradigms, although frequently unspoken, of the traditional ethnography is that the "primitive," the "others," the "natives" were unable to speak for themselves. It was assumed that the task of ethnographers was to reveal the natives' cultures and to present them as fully as possible to the "civilized" readers. In the 1980s, however, these ideas were challenged and under serious critique in what Marcus \& Fischer (1986) have called as the "crisis of representation." Thet asserted that ethnographers could no longer claim their authority over the "Others" and the totality of culture they try to represent in their writings.

Consequently, as Clifford (1986) argues, "Ethnographic truths are thus inherently partialcommitted and incomplete.' (p. 7). An ethnographer, thus, must be ready to admit that, in Denzin's (1997) words, "No text can do everything at once. The perfect ethnography cannot be written" (p.287). So do, certainly, media ethnographers researching diasporic communities.

\section{REFERENCES}

Abdulrehman, M. S. (2015). Reflections on native ethnography by a nurse researcher. Journal of Transcultural Nursing, 28(2), 152-158.

Abu-Lughod, L. (1988). Fieldwork of a dutiful daughter. In S. Altorki, \& C. Fawzi El-Solh, Arab women in the field: Studying your own society (pp. 139-161). Syracuse, NY: Syracuse University Press.

Acosta-Alzuru, C. (2005). Home is where my heart is: reflections on doing research in my native country. Popular Communication, 3(3), 181-193.

Aguilar, J. A. (1981). Insider research: An ethnography of a debate. In D. A. Messerschmidt, Anthropologists at home in North America: Methods and issues in the study of one's own society (pp. 15-26). Cambridge: Cambridge University Press.

Alasuutari, P. (1999). Introduction: Three phases of reception studies. In P. Alasuutari (Ed.), Rethinking the media audience: The new agenda (pp. 1-21). London: Sage.

Allor, M. (1988). Relocating the site of the audience. Critical Studies in Mass Communication, 5, 217-233.

Altorki, S. (1988). At home in the field. In S. Altorki, \& C. Fawzi El-Solh, Arab women in the field: Studying your own society (pp. 49-68). Syracuse, NY: Syracuse University Press.

Altorki, S., \& Fawzi El-Solh, C. (Eds.). (1988a). Arab women in the field: Studying your own society. Syracuse, NY: Syracuse University Press.

Altorki, S., \& Fwazi El-Solh, C. (1988b). Introduction. In S. Altorki, \& C. Fawzi El-Solh, Arab women in the field: Studying your own society (pp. 1-23). Syracuse, NY: Syracuse University Press.

Ang, I. (1985). Watching Dallas: Soap opera and melodramatic imagination. London \& New York: Metheun. 
Ang, I. (1996). Ethnography and radical contextualism in audience studies. In J. Hay, L. Grossberg, E. Wartella (Eds.), The audience and its landscape (pp. 247-264). Boulder: Westview Press.

Appadurai, A. (1988). Putting hierarchy in its place. Cultural Anthropology, 3(1), 36-49.

Appadurai, A. (1996). Modernity at large: Cultural dimension of globalization. Minneapolis: University of Minnesota Press.

Asad, T. (2002). From the history of colonial anthropology to the anthropology of Western hegemony. In J. Vincent (Ed.), The anthropology of politics: A reader in ethnography, theory, and critique (pp. 133-142). Malden, MA: Blackwell Publishers.

Balzer, M. M. (1995). What's "native" about non-Russian anthropology? In M. M. Balzer (Ed.), Culture incarnates: Native anthropology from Russia (pp. 3-30). Armonk, NY: M.E. Sharpe.

Bhandari, K. B. (2019). Media ethnography: Demands alternative. The Qualitative Report, 24(1), 193-203.

Bird, E. (1992). Travels in nowhere land: Ethnography and the "impossible" audience. Critical Studies in Communication, 9, 250-260.

Bird, E. (2003). The audience in everyday life: Living in a media world. Routledge: New York and London.

Buroway, M. (2000). Introduction: Reaching for the global. In M. Buroway, et al. (Eds.), Global ethnography: Forces, connections, and imaginations in a postmodern world (pp. 1-40). Berkeley: University of California Press.

Clifford, J. (1986). Partial truths. In J. Clifford \& G. E. Marcus, (Eds.), Writing culture: The poetics and politics of ethnography (pp. 1-26). Berkeley: University of California Press.

Clifford, J. (1997). Routes: Travel and translation in the late twentieth century. Cambridge, MA: Harvard University Press.

Couldry, N. (2003). Passing ethnographies: Rethinking the sites of agency and reflexivity in a mediated world. In P. M. Murphy and M. M. Kraidy, Global media studies: Ethnographic perspectives (pp. 40-56). New York and London: Routledge.

Denzin, N. K. (1997). Interpretive ethnography: Ethnographic practices for the $21^{\text {st }}$ century. Thousand Oaks: Sage Publications.

Diraj, M. (2010). Muslim punks online: A diasporic Pakistani music subculture on the Internet. South Asian Popular Culture, 8(2), 181-194.

Falzon, M. A. (2009). Multi-sited ethnography: Theory, praxis, and locality in contemporary research. In M. A. Falzon (ed). Multi-sited ethnography: Theory, praxis, and locality in contemporary research (pp. 1-23). Surrey, UK \& Burlington, USA: Ashgate.

Ferguson, J. (2009). Novelty and method: Reflections on global fieldwork. In M. A. Falzon (ed). Multisited ethnography: Theory, praxis, and locality in contemporary research (pp. 195-207). Surrey, UK \& Burlington, USA: Ashgate.

Gille, Z., \& Riain, S. Ó. (2002). Global ethnography. Annual Review of Sociology, 28, 271-295.

Gilroy, P. (1994). Diaspora. Paragraph, 17(1), 207-212.

Grossberg, L. (1988). Wandering audiences, nomadic critics. Cultural Studies, 2(3), 377-390.

Gupta, A., \& Ferguson, J. (1997). Discipline and practice: "The field" as site, method, and location in anthropology. In A. Gupta \& J. Ferguson, Anthropological locations: Boundaries and grounds for a field science (pp. 1-46). Berkeley: University of California Press.

Hall, S. (1973). Encoding and decoding in the television discourse. Birmingham: Centre of Cultural Studies, University of Birmingham.

Hannerz, U. (2003). Being there . . . and there . . . and there: Reflections on multi-site ethnography. Ethnography, 4(2), 201-216.

Hannoum, A. (2011). The (re)turn of the native: Ethnography, anthropology, and nativism. In H. Seneviratne (Ed.), The anthropologist and the native: Essays for Gananath Obeyesekere (pp. 423-444). Anthem Press.

Hendry, J. (2003 ). An ethnography in the global arena: Globography perhaps? Global Networks, 3(4), 497512.

Indiyanto, A. (2012). The politics of belonging: Plundering the local, claiming the global. Humaniora, 24(3), 245-254.

Isaacs, E. (2016). The value of rapid ethnography. In B. Jordan, Advancing ethnography in corporate environments: Challenges and emerging opportunities (pp. 92-107). New York: Routledge.

Jacobs-Huey, L. (2002). The natives are gazing and talking back: Reviewing the problematics of positionality, voice, and accountability among "native" anthropologists. American Anthropologist, 104(3), 791-804.

Jeffrey, B., \& Troman, G. (2004). Time for ethnography. British Education Research Journal, 30(4), 535-548.

Junnilainen, L. \& Luhtakallio. E. (2015). Media Ethnography. In Mazzoleni (ed.). The International Encyclopaedia of Political Communication. John Wiley \& Sons.

Knoblauch, H. (2005). Focused ethnography. Forum: Qualitative Social Research, 6(3). Retrieved from http://www.qualitative-research.net/index.php/fqs/ article/view/20/43, August 24, 2019.

Koentjaraningrat. (1982). Anthropology in developing countries. In H. Fahim, (Ed.), Indigenous anthropology in non-Western countries: Proceedings of a Burg Wartenstein Symposium (pp. 176-191). Durham, NC: Carolina Academic Press. 
Kraidy, M. M. (1996). Towards a semiosphere if hybrid identities: A native ethnography of glocalization. Unpublished doctoral dissertation, Ohio University, Athens.

Kraidy, M. M., \& Murphy, P. D. (2003). Media ethnography: Local, global, or translocal? In P. M. Murphy and M. M. Kraidy, Global media studies: Ethnographic perspectives (pp. 299-307). New York and London: Routledge.

Kuklick, H. (1997). After Ishmael: The fieldwork tradition and its future. In A. Gupta \& J. Ferguson, Anthropological locations: Boundaries and grounds for a field science (pp. 47-65). Berkeley: University of California Press.

Kuwayama, T. (2004). Native anthropology: The Japanese challenge to Western academic hegemony. Melbourne: Trans Pacific Press.

Lavie, S., \& Swedenburg, T. (1996). Between and among the boundaries of culture: Bridging text and lived experience in the third time space. Cultural Studies, 10(1), 154-179.

Malinowski, B. (1961). Argonauts of the Western Pacific: An account of native enterprise and adventure in the archipelagoes of Melanesian New Guinea. New York: E. P. Dutton \& Co., Inc.

Marcus, G. E. (1995). Ethnography in/of the world system: The emergence of multi-sited ethnography. Annual Review of Anthropology, 24, 95-117.

Marcus, G. E. (1998). Ethnography through thick and thin. Princeton, NJ: Princeton University Press.

Marcus, G. E. (1999). What is at stake-and is not-in the idea and practice of multi-sited ethnography. Canberra Anthropology, 22(2), 6-14.

Marcus, G. E. (2002). Beyond Malinowski and after Writing Culture: On the future of cultural anthropology and the predicament of ethnography. The Australian Journal of Anthropology, 13(2), 191-199.

Marcus, G. E. (2011). Multi-sited ethnography: Five or six things I know about it now. In S. Coleman \& P. von Hellerman (eds.), Multi-sited ethnography: Problems and possibilities in the translocation of research methods (pp. 16-32). New York \& London: Routledge.

Marcus, G. E., \& Fischer, M. M. (1986). Anthropology as cultural critique: An experimental moment in the human sciences. Chicago: The University of Chicago Press.

McLuhan, M. (1964). Understanding media, the extension of man. New York: Mentor Book.

Messerschmidt, D. A. (Ed.) (1981). Anthropologists at home in North America: Methods and issues in the study of one's own society. Cambridge: Cambridge University Press.

Morley, D. (2000). Home territories: Media, mobility, and identity. London \& New York: Routledge.

Murphy, P. (2011). Locating media ethnography. In V. Nightingale, The handbook of media audiences (pp. 380-401). West Sussex, UK: John Wiley \& Sons.

Murphy, P. \& Kraidy, M. (2003). Towards an ethnographic approach to global media studies. In P. Murphy \& M. Kraidy, Global media studies, Ethnographic perspectives. New York: Routledge.

Paterson, C. A. (2017). The ethnography of digital journalism. In B. Franklin \& S. Eldredge (eds.) The Routledge Companion to Digital Journalism Studies (pp. 108-116). Routledge: Abingdon, Oxfordshire.

Pink, S. \& Morgan, S. (2013). Short-term ethnography: Intense routes to knowing. Symbolic Interaction, 36(3), 351-361.

Radway, J. A. (1984). Reading the romance: Women, patriarchy, and popular culture. The University of North Carolina Press: Chapel Hill.

Radway, J. A. (1988). Reception study: Ethnography and the problems of dispersed audiences and nomadic subjects. Cultural Studies, 2(3), 359-376.

Rits, R.C. (1980). Blitzkrieg ethnography: On the transformation of a method into a movement. Educational Researcher, 9(2), 8-10.

Ryang, S. (2005). Dilemma of a native: On location, authenticity, and reflexivity. The Asia Pacific Journal of Anthropology, 6(2), 143-157.

Setianto, Y. P., (2016). Media use and mediatization of transnational political participation: The case of transnational Indonesians in the United States. Unpublished doctoral dissertation, Ohio University, Athens.

Shumow, M. (2010). "A foot in both worlds": Transnationalism and media use among Venezuelan immigrants in South Florida. International Journal of Communication, 4, 377-397.

Sun, W. \& Sinclair, J. (Eds.). (2016). Media and communication in the Chinese diaspora: Rethinking transnationalism. London \& New York: Routledge.

Tosoni, S. \& Stiernstedt, F. (2016). Media ethnography for busy people. In Kramp, L et al. (eds.). Politics, civil society, and participation: Media and communications in a transforming environment. Bremen.

Võ, L. T. (2000). Performing ethnography in AsianAmerican communities: Beyond the insider-versusoutsider perspective. In M. F. Manalansan, IV, Cultural compass: Ethnographic exploration of Asian America (pp. 17-37). Philadelphia: Temple University Press.

Wardana, A. (2013). "Living in-between": The multiple integration trajectories of the London Indonesian Muslim immigrants. Unpublished doctoral dissertation, University of Essex. 
Weston, K. (1997). The virtual anthropologist. In A. Gupta \& J. Ferguson, Anthropological locations: Boundaries and grounds for a field science (pp. 163-184). Berkeley: University of California Press.

Widjanarko, P. (2007). Homeland, identity and media: A study of Indonesian transnational Muslims in New York City. Unpublished doctoral dissertation, Ohio University, Athens.
Wolcott, H. W. (1999). Ethnography: A way of seeing. Walnut Creek CA: Altamira Press.

Yosihimura, A. (2015). To believe and not to believe: A native ethnography of Kanashibari in Japan. The Journal of American Folklore, 128(508), 146-148.

Zulfikar, T. (2014). Researching my own backyard: inquiries into an ethnographic study. Ethnography and Education, 9(3), 373-386. 